\title{
Adaptive Educational Hypermedia Systems based on Learning Styles: The Case of Adaptation Rules
}

\author{
https://doi.org/10.3991/ijet.v12i05.6967 \\ Xanthippi Tsortanidou \\ University of Thessaly, Volos, Greece \\ xanthippi.tsortanidou@gmail.com \\ Charalampos Karagiannidis \\ University of Thessaly, Volos, Greece \\ karagianeuth.gr \\ Adamantios Koumpis \\ Universität Passau, Passau, Germany \\ adamantios.koumpis@gmail.com
}

\begin{abstract}
This paper investigates the pedagogical basis of Adaptive Educational Hypermedia Systems (AEHS) that incorporate Learning Styles in order to accommodate user's learning style preferences and needs. Therefore, AES adapt the learning content, its presentation and navigation to the user's learning style preferences. We collect thirty three (33) Adaptive and Intelligent Web-based Educational Systems (AIWBES) that incorporate learning styles and discuss twenty of them, namely the AEHS, as the remaining are Intelligent Tutorng Systems. The main achievement of this work is the investigation of AEHS' pedagogical basis in terms of adaptation rules. We conclude that these systems follow similar patterns in their adaptation logic.
\end{abstract}

Keywords—adaptive educational hypermedia systems, learning styles, pedagogical basis

\section{Introduction}

The Internet and World Wide Web (WWW) offer new possibilities for innovative instruction, as the development of hypermedia educational systems facilitates learning and utilizes learning as an active process, in which users can explore alternative learning paths. The utilization of web is more beneficial when it follows a student-oriented approach in order to reinforce the learning experience [1]. Many researchers conclude that learning environments should take into consideration the individual differences among users/learners. The fundamental idea of personalization, namely individualized instruction, is that education should not be restricted by time, place or any other obstacle and should be adapted to constantly changing demands of users', namely their capabilities, preferences, knowledge, skills, etc. [2]. Within this context, the user 
modelling is vital to process of personalization, as the system assembles the most appropriate personalized course for each individual. Therefore, AEHS cater to needs of each individual user, adapts to learning goals/tasks, level of knowledge, background, experience, traits, context of work, prerequisite knowledge and interests [3]. Several terms for characterizing the AES that incorporate learning styles are used, such as LSAES (Learning Style based Adaptive Educational System) [4], [5], LS -AE (Learning Style-Adaptive Enviornments) [6], LS-BAEHSS (Learning Styles-Based Adaptive Educational Hypermedia Systems) [7], etc. In our study we adopt a more general chracterization, as AEHS that incorporate learning styles. There are only a few studies that provide overview of such systems, which main source of adaptation are learning styles, such as [8], [9], [10], [11], [7], [12], [6], [13], etc. In our study we categorize the undermentioned systems by learning style models and adaptation rules. Regarding adaptation rules, Popescu et al. [4] propose a model, ULSM (Unified Learning Style Model), a characteristic-based modeling approach for characterizing the students from their learning preferences. Also, Vandewaetere et al. [12], present an overview of pathways of adaptation in computer-based adaptive learning environments. Consequently, the aforementioned reasons rendering the investigaton of pedagogical basis a daunting task.

The present work investigates AES which incorporate learning styles in order to adapt the learning content, its presentation and navigation to the user's learning style preferences. As the adaptation to the learning style has been considered an important factor towards personalized instruction and adaptation rules are required for adaptation, we consider that is purposeful to examine the adaptation rules of these systems.

\section{Methodology}

We collect thirty three (33) Adaptive and Intelligent Web-based Educational Systems (AIWBES) that incorporate learning styles and discuss twenty of them, namely the AEHS, as shown by Table 1, as the remaining are Intelligent Tutorng Systems. We attempt to gather all the existing AIWBES and we analyze them in accordance with authors' description, because many of them are not available on-line. Based on methodology of literature review, we search for relevant works in library databases, greek and foreign, through google scholar and emails to various researchers. Based on the provided educational material, we conclude which adaptation rules are followed by these AEHS. The research questions are: What is the pedagogical basis of AEHS? What are the adaptation rules that following these systems in order to adapt the educational material to user's learning style preferences? In particular, the search was performed using keywords, such as adaptive educational stystems, intelligent systems, personalization and adaptative systems, learning styles, learning styles and adaptive systems, pedagogical basis at adaptive systems, adaptation rules, adaptation rules and adaptive systems, categorization of adaptive systems, etc. We searced at journals, such as Computers \& Education, Review of Educational research, Educational Technology \& Society, Journal of Business Education, User Modeling and User-Adapted Interaction, International Journal of Artificial Intelligence in Education, Instructional 
science, Applied Artificial Intelligence, etc., at conference proceedings, such as Learning Technologies Conference, Conference on Hypertext and Hypermedia, Conference on Intelligent Tutoring Systems, WWW Conference, International Conference on E-Learning and Games, IEEE International Conference, Conference on Computers in Education, etc.

\section{Brief description of AEHS based on Learning Styles}

We gather thirty three (33) Adaptive and Intelligent Web-based Educational Systems (AIWBES) from 1996 to 2014, as we can see at Table 1, and discuss twenty of them. Specifically, we analyze the AEHS and refer some basic features of them, as we can see at Table 2. AIWBESystems in order to be adaptive, they build a model of goals, preferences and knowledge of each individual user and according to it, the system is adapted to the user's needs [3]. According to [14] "AEH systems build a model of the individual user/learner, and apply it for adaptation to that user. In this sense, they can be considered as a sub-domain of ITS" (pp.31). The AEHS are the following:

"CS383, Computer Systems" is a hypermedia courseware and an adaptive hypermedia interface were developed in order to personalize the presentation of course material to user's learning style, based on the Felder and Silverman Learning Style Model. It introduces briefly university students to various areas of Computer Science [15].

"Arthur" is a Web-based instruction system that provides adaptive instruction to implement the many-to-one relationship in order to teach Physics and CCC programming language. There are three instructors, each of which has on his own section, audio, visual, tactile or textual and different instruction style is used each time [16].

"iWeaver" is a Web-based Adaptive Learning Environment that provides an introductory course on computer programming in accord with user's learning styles. The system accommodates the learning styles and implements different forms of instruction, based on Dunn and Dunn's Learning Style Model [6].

"ILASH" is an Educational Hypermedia System that incorporates the summarising and questioning strategies into hypermedia. The system includes different adaptive techniques embedded in the text and link structure to support the use of strategies. The system contains courseware and aims at GCSE-level students, including an adaptive session about "The behaviour of waves" and a non-adaptive session about "The Solar System" in the field of Physics [17].

"FEIJOO.NET" is an Adaptive System Hypermedia which adapts content and its presentation to the user's learning style, namely Theorists and Activist. The system aims at university students [18].

"INSPIRE" (INtelligent System for Personalized Instruction in a Remote Environment) is an Adaptive Educational Hypermedia System that personalizes the presentation of educational material in accordance with users' learning style, based on the Honey and Mumford's Learning Style Model. Also, suggests a navigation route based on their level of knowledge, aiming to teach Computer Architecture [19]. 
"AES-CS" (Adaptive Educational System based on Cognitive Styles) is an Adaptive Educational System based on user's cognitive style and aims to teach "Multimedia Systems Technology" at university students. The system adopts the Witkin's Cognitive Style Model [20].

"LSAS" is a Hypermedia Educational System that incorporates the sequencing of pages and structure, employing two different presentation style of user interface templates in order to caters learner's preferences. The system aims to teach Geography and incorporates the global and sequential learning style according to FelderSilverman Learning Style Model [17].

"MOT" is a tool which allows the incorporation of different learning styles into adaptive educational hypermedia applications, based on Kolb's Learning Style Model [10].

"TANGOW" (Task-based Adaptive learNer Guidance On the Web) adapts the course structure and sequencing to the student's profile based on Felder-Silverman learning style model [21].

"WHURLE" (Web-based Hierarchical Universal Reactive Learning Environment) is an Adaptive Web-based Educational System (AWBES) that adapts content to visual-verbal preferences [22].

"MASPLANG" (MultiAgent System PLAtforma de Nueva Generation) is elearning system that provides personalized contents, navigation tools and navigation strategies dependant on the user's learning style and cognitive state, based on Felder and Silverman Learning Style Model [23].

"DEUS" (Digital Environment Utilising Styles) is an Adaptive Educational Hypermedia System that incorporates the sequential and global learning style of Felder and Silverman's Learning Style Model. The system aims at primary school students and its domain is Life Cycles [24].

"AHA! System: Version 3.0" (Adaptive Hypermedia Architecture) is a generalpurpose adaptive hypermedia system and implement learning styles [25].

"WELSA" (Web-based Educational system with Learning Style Adaptation) is an Intelligent and Adaptive Web-based Educational System that aims at adapting the courses to the student's learning style preferences, teaching a course module in the area of Artificial Intelligence [26].

"PALS2" is an Adaptive Web-based Educational System that provides learners with personalized learning content based on their learning styles. This system aims at university students and teaches Semantic Network course, based on Jackson's Learning Styles Profiler [27].

"AEHS-LS" (Adaptive E-Learning Hypermedia System based on Learning Style) is an Adaptive E-Learning Hypermedia System that adapts content presentation to student learning styles in order to present the appropriate content, format and media type. The system aims to teach Java programming language and adopts the VARK Learning Style Model [28].

"MATHEMA" is a Web-based Adaptive Educational Hypermedia System that aims at teaching senior High School students or novices of Higher Education about Physics and especially electromagnetism [11]. 
"AMDPC" (Adaptation with Multi-Dimensional Personalization Criteria) is an Adaptive Learning System, based on Witkin's Cognitive Style Model and FelderSilverman's Learning Style Model. The provision of personalized content and presentation layout based on learning styles, while personalized user interfaces and navigation strategies based on cognitive styles. This system regards Computer Networks [29].

"LS-AEHS" (Learning Style based on Adaptive E-learning Hypermedia System) is a system which integrates learning styles into adaptive e-learning hypermedia. This system addresses university students in order to teach Chemistry, by adapting content presentation to students' learning styles [30].

Table 1. Adaptive and Intelligent Web-based Educational Systems (AIWBES)

\begin{tabular}{|c|c|c|c|c|}
\hline $\begin{array}{l}\text { AIWBES* based } \\
\text { on LSM }\end{array}$ & Date & $\begin{array}{l}\text { Educational } \\
\text { stage }\end{array}$ & Domain & $\begin{array}{l}\text { Learning Style Model } \\
\text { (LSM) }\end{array}$ \\
\hline CS383 & 1996 & Higher & Computer Science & FSLSM \\
\hline Arthur & 1999 & Higher & Physics \& C++ & Instruction styles \\
\hline iWeaver & 2002 & Higher & Java programming language & $\begin{array}{c}\text { Dunn \& Dunn's \& psycholog- } \\
\text { ical preferences }\end{array}$ \\
\hline ILASH & 2003 & Secondary & Physics & $\begin{array}{l}\text { Summarising, questioning } \\
\text { strategies }\end{array}$ \\
\hline FEIJOO.NET & 2003 & Higher & Undefined & $\begin{array}{l}\text { Inspired by Honey and Mum- } \\
\text { ford's }\end{array}$ \\
\hline INSPIRE & 2003 & Higher & Computer Architecture & Honey \& Mumford's \\
\hline AES-CS & 2003 & Higher & $\begin{array}{c}\text { Multimedia Systems Tech- } \\
\text { nology }\end{array}$ & Witkin's FI/FD \\
\hline LSAS & 2003 & Secondary & Geography & FSLSM \\
\hline MOT & 2004 & -- & General-purpose & Kolb's \\
\hline TANGOW & 2004 & -- & Independent & FSLSM \\
\hline WHURLE & 2004 & Higher & Independent & FSLSM \\
\hline MAS-PLANG & 2004 & Higher & Computer Science & FSLSM \\
\hline FlexiOLM & 2004 & Higher & $\mathrm{C}$ programming language & FSLSM \\
\hline CIMEL-ITS & 2005 & Higher & $\mathrm{CS} 1$ & FSLSM \\
\hline First Aid For you & 2005 & Secondary & First Aid & FSLSM \\
\hline $\begin{array}{l}\text { Heritage alive } \\
\text { learning }\end{array}$ & 2006 & Higher & Architecture & FSLSM \\
\hline DEUS & 2006 & Primary & Life cycles & FSLSM \\
\hline EDUCE & 2006 & Secondary & Static Electricity & Gardner's theory of MI \\
\hline $\begin{array}{l}\text { Vectors in Physics } \\
\text { \& Mathematics }\end{array}$ & 2007 & Secondary & $\begin{array}{c}\text { Vectors in Physics \& Math- } \\
\text { ematics }\end{array}$ & $\begin{array}{l}\text { Biggs' surface vs. deep stu- } \\
\text { dent approach }\end{array}$ \\
\hline PALS2 & 2007 & Higher & Semantic Network & $\begin{array}{c}\text { Jackson's Learning Styles } \\
\text { Profiler (LSP) }\end{array}$ \\
\hline SAVER & 2007 & Higher & Artificial Intelligence & FSLSM \\
\hline AHA! (3.0) & 2007 & -- & General-purpose & $\begin{array}{c}\text { Instructional strategies \& } \\
\text { meta-strategies }\end{array}$ \\
\hline TSAL & 2008 & Secondary & Mathematics & Keefe's Model \\
\hline WELSA & 2008 & Higher & Computer Science & ULSM \\
\hline
\end{tabular}


Paper-Adaptive Educational Hypermedia Systems based on Learning Styles: The Case of Adaptation...

\begin{tabular}{|c|c|c|c|c|}
\hline TANGRAM & 2009 & -- & General-purpose & FSLSM \\
\hline AEHS-LS & 2011 & Higher & Java programming language & VARK \\
\hline Mag & 2011 & Higher & $\begin{array}{c}\text { Learning programming } \\
\text { languages }\end{array}$ & Dunn \& Dunn's \\
\hline PROTUS 2.0 & 2012 & Higher & Java programming language & FSLSM \\
\hline MATHEMA & 2012 & $\begin{array}{c}\text { Secondary/ } \\
\text { Higher }\end{array}$ & Physics & Kolb's \\
\hline UZWEBMAT & 2012 & Secondary & Mathematics & VAK \\
\hline AMDPC & 2013 & Higher & Computer Networks & Witkin's FI/FD, FSLSM \\
\hline LS-AEHS & 2013 & Higher & Chemistry & Honey \& Mumford's \\
\hline OSCAR CITS & 2014 & Higher & Computer Science & FSLSM \\
\hline
\end{tabular}

*Adaptive and Intelligent Web-based Educational Systems (AIWBES) [3]

Table 2. Basic features of AEHS

\begin{tabular}{|c|c|c|c|c|c|}
\hline AEHS & $\begin{array}{l}\text { Student Mod- } \\
\text { elling Ap- } \\
\text { proach }\end{array}$ & Learning Style Model & $\begin{array}{l}\text { To what is } \\
\text { adapted }\end{array}$ & What is adapted & Research \\
\hline CS383 & $\begin{array}{c}\text { Index of Learn- } \\
\text { ing Styles } \\
\text { Questionnaire } \\
\end{array}$ & FSLSM & Learning style & $\begin{array}{c}\text { Content presenta- } \\
\text { tion }\end{array}$ & Empirical \\
\hline Arthur & $\begin{array}{l}\text { Learner's } \\
\text { performance in } \\
\text { the tests }\end{array}$ & Instruction styles & Performance & $\begin{array}{l}\text { Instructional style } \\
\text { [visual-interactive, } \\
\text { auditory-text, } \\
\text { auditory-lecture, } \\
\text { text] }\end{array}$ & Empirical \\
\hline iWeaver & $\begin{array}{l}\text { Building Excel- } \\
\text { lence Survey }\end{array}$ & $\begin{array}{c}\text { Dunn \& Dunn Model } \\
\text { \& four psychological } \\
\text { learner preferences } \\
\text { [Impulsive,Reflective\& } \\
\text { Global,Analytical] }\end{array}$ & $\begin{array}{l}\text { Learning style, } \\
\text { experience rat- } \\
\text { ings, } \\
\text { navigational } \\
\text { choices }\end{array}$ & $\begin{array}{l}\text { Content, content } \\
\text { navigation, (rec- } \\
\text { ommendation of) } \\
\text { media experience } \\
\text { (choice/no choice) }\end{array}$ & Empirical \\
\hline ILASH & ---- & $\begin{array}{l}\text { Summarising \& ques- } \\
\text { tioning strategies }\end{array}$ & $\begin{array}{c}\text { Knowledge state/ } \\
\text { progress }\end{array}$ & $\begin{array}{l}\text { Layout presenta- } \\
\text { tion, } \\
\text { Navigation sup- } \\
\text { port }\end{array}$ & Empirical \\
\hline FEIJOO.NET & $\begin{array}{l}\text { Test of } \\
\text { CHAEA }\end{array}$ & $\begin{array}{l}\text { Inspired by the Honey } \\
\& \text { Mumford's model } \\
\text { [Theorists\&Activists] }\end{array}$ & Learning style & $\begin{array}{l}\text { Content, content } \\
\text { presentation }\end{array}$ & Unknown \\
\hline INSPIRE & $\begin{array}{l}\text { Learning Style } \\
\text { Questionnaire }\end{array}$ & $\begin{array}{l}\text { Honey \& Mumford's } \\
\text { Model }\end{array}$ & $\begin{array}{c}\text { Knowledge, } \\
\text { learning style, } \\
\text { learning goal, last } \\
\text { login, favourite } \\
\text { pages, time spent }\end{array}$ & $\begin{array}{l}\text { Lesson contents, } \\
\text { navigational route }\end{array}$ & Empirical \\
\hline AES-CS & $\begin{array}{l}\text { Group Embed- } \\
\text { ded Figures } \\
\text { Test }\end{array}$ & Witkin's FI/FD & $\begin{array}{c}\text { Cognitive style, } \\
\text { level of } \\
\text { knowledge }\end{array}$ & $\begin{array}{c}\text { Presentation, } \\
\text { navigation, in- } \\
\text { structional strate- } \\
\text { gies }\end{array}$ & Empirical \\
\hline LSAS & $\begin{array}{c}\text { Index of Learn- } \\
\text { ing Styles } \\
\text { Questionnaire }\end{array}$ & $\begin{array}{c}\text { FSLSM } \\
\text { [Global\&sequential] }\end{array}$ & Learning styles & $\begin{array}{l}\text { Presentation, } \\
\text { navigation }\end{array}$ & Empirical \\
\hline MOT & $\begin{array}{l}\text { Monitoring the } \\
\text { learner's }\end{array}$ & $\begin{array}{c}\text { Kolb's Learning Style } \\
\text { Model }\end{array}$ & Learning style & $\begin{array}{l}\text { Instructional } \\
\text { strategies }\end{array}$ & Unknown \\
\hline
\end{tabular}


Paper-Adaptive Educational Hypermedia Systems based on Learning Styles: The Case of Adaptation...

\begin{tabular}{|c|c|c|c|c|c|}
\hline & behavior & [Diverger\&converger] & & & \\
\hline TANGOW & $\begin{array}{c}\text { Inventory of } \\
\text { Learning Styles }\end{array}$ & $\begin{array}{c}\text { FSLSM } \\
\text { [Sensing/intuitive \& } \\
\text { sequential/global] }\end{array}$ & $\begin{array}{l}\text { background, age, } \\
\text { language, previ- } \\
\text { ous use of hyper- } \\
\text { media, learning } \\
\text { styles, } \\
\text { student actions \& } \\
\text { teaching strategy }\end{array}$ & $\begin{array}{c}\text { Content, sequence } \\
\& \text { structure, guid- } \\
\text { ance }\end{array}$ & Empirical \\
\hline WHURLE & $\begin{array}{c}\text { Inventory of } \\
\text { Learning Styles }\end{array}$ & $\begin{array}{c}\text { FSLSM } \\
\text { [Visual\&verbal] }\end{array}$ & $\begin{array}{l}\text { Learning prefer- } \\
\text { ences }\end{array}$ & $\begin{array}{l}\text { Mode of presenta- } \\
\text { tion }\end{array}$ & Empirical \\
\hline $\begin{array}{l}\text { MAS- } \\
\text { PLANG }\end{array}$ & $\begin{array}{c}\text { Inventory of } \\
\text { Learning Styles }\end{array}$ & FSLSM & $\begin{array}{l}\text { knowledge level, } \\
\text { learning style }\end{array}$ & $\begin{array}{l}\text { Content, content } \\
\text { presenation }\end{array}$ & Unknown \\
\hline DEUS & $\begin{array}{c}\text { Inventory of } \\
\text { Learning Styles }\end{array}$ & $\begin{array}{c}\text { FSLSM } \\
\text { [Global\&sequential] }\end{array}$ & Learning style & $\begin{array}{l}\text { structuring of } \\
\text { information }\end{array}$ & Empirical \\
\hline PALS2 & $\begin{array}{c}\text { Jackson's } \\
\text { Learning Styles } \\
\text { Profiler ques- } \\
\text { tionnaire }\end{array}$ & $\begin{array}{l}\text { Jackson's Learning } \\
\text { Styles Profiler }\end{array}$ & $\begin{array}{l}\text { learning style, } \\
\text { background } \\
\text { knowledge }\end{array}$ & $\begin{array}{l}\text { Pedagogical } \\
\text { strategies, } \\
\text { presentation, } \\
\text { content }\end{array}$ & Empirical \\
\hline AHA! (3.0) & $\begin{array}{l}\text { Instructional } \\
\text { metastrategies } \\
\text { to infer the } \\
\text { learner's pref- } \\
\text { erences }\end{array}$ & defined by the author & $\begin{array}{c}\text { Learning styles \& } \\
\text { preferences }\end{array}$ & $\begin{array}{l}\text { Instructional } \\
\text { strategies }\end{array}$ & Empirical \\
\hline WELSA & $\begin{array}{c}\text { Analysis of the } \\
\text { learners' inter- } \\
\text { actions with the } \\
\text { system }\end{array}$ & ULSM & $\begin{array}{l}\text { Learning prefer- } \\
\text { ences }\end{array}$ & $\begin{array}{c}\text { Navigation, educa- } \\
\text { tional resources }\end{array}$ & Empirical \\
\hline AEHS-LS & $\begin{array}{l}\text { Filling the } \\
\text { VARK ques- } \\
\text { tionnaire or } \\
\text { selecting the } \\
\text { learning style } \\
\text { based on in- } \\
\text { formation }\end{array}$ & VARK & $\begin{array}{l}\text { knowledge level, } \\
\text { learning style }\end{array}$ & $\begin{array}{l}\text { presentation of } \\
\text { content (content, } \\
\text { format \& media } \\
\text { type) }\end{array}$ & Empirical \\
\hline МАТНЕМА & $\begin{array}{l}\text { Kolb's Learning } \\
\text { Style Inventory }\end{array}$ & $\begin{array}{l}\text { Kolb's Learning Style } \\
\text { Model }\end{array}$ & $\begin{array}{l}\text { learning goal, } \\
\text { knowledge level } \\
\text { for each main } \\
\text { concept/ learning } \\
\text { goal, Web experi- } \\
\text { ence, learning } \\
\text { style, preference } \\
\text { for visual and/or } \\
\text { verbal feedback \& } \\
\text { preference for the } \\
\text { kind of navigation }\end{array}$ & $\begin{array}{c}\text { Presentation, } \\
\text { navigation, se- } \\
\text { quence of content, } \\
\text { group formation, } \\
\text { peer help, feed- } \\
\text { back }\end{array}$ & Empirical \\
\hline AMDPC & $\begin{array}{l}\text { Group Embed- } \\
\text { ded Figures } \\
\text { Test \& Index of } \\
\text { Learning Style } \\
\text { questionnaire } \\
\end{array}$ & $\begin{array}{c}\text { FD/FI cognitive style } \& \\
\text { FSLSM }\end{array}$ & $\begin{array}{l}\text { Learning style, } \\
\text { cognitive style }\end{array}$ & $\begin{array}{l}\text { presentation, } \\
\text { content }\end{array}$ & Empirical \\
\hline LS-AEHS & $\begin{array}{l}\text { Learning Style } \\
\text { Questionnaire }\end{array}$ & $\begin{array}{c}\text { Honey \& Mumford's } \\
\text { Model }\end{array}$ & Learning style & $\begin{array}{l}\text { Presentation, } \\
\text { navigation }\end{array}$ & Empirical \\
\hline
\end{tabular}




\section{Classification of AEHS in learning style families}

Among the several definitions that are used to describe the term "learning syles", the most frequenlty used and generally accepted is Keefe's [31] who defined them as "characteristic cognitive, affective and psychological behaviours that serve as relatively stable indicators of how learners perceive, interact with and respond to the learning environment" [p. 4]. Learning styles sometimes used interchangeably with cognitive styles, which can be defined as a person's approach in perceiving, remembering, processing [32] and organizing information [33], [34]. In current study, we categorize the AEHS in accord with [35] learning styles families, as we can see at Table 3. Coffield et al. [35] sort learning styles models into five families, drawing on the classification of learning styles by Curry [36]. Learning style models that are influenced by genetics and refer to fixed, inherited traits and about the interaction of personality and cognition are placed at the left-hand end of the continuum. Moving along it, learning styles models are based on "the idea of dynamic interplay between self and experience" [35] [pp. 20]. Personal and environmental factors, effects of curriculum design, culture, teaching and assessment tasks on how students opt or reject particular learning strategies are placed at the right-hand end of the continuum [35].

Table 3. Families of learning styles

\begin{tabular}{|c|c|c|c|c|}
\hline $\begin{array}{l}\text { Constitutionally- } \\
\text { based learning } \\
\text { styles and prefer- } \\
\text { ences }\end{array}$ & $\begin{array}{l}\text { Cognitive } \\
\text { structure }\end{array}$ & $\begin{array}{l}\text { Stable per- } \\
\text { sonality type }\end{array}$ & $\begin{array}{c}\text { Flexibly stable learning } \\
\text { preferences }\end{array}$ & $\begin{array}{c}\text { Learning approaches } \\
\text { \& strategies }\end{array}$ \\
\hline iWeaver, AEHS-LS & $\begin{array}{l}\text { AES-CS, } \\
\text { AMDPC }\end{array}$ & PALS2 & $\begin{array}{c}\text { CS383, iWeaver, } \\
\text { FEIJOO.NET, INSPIRE, } \\
\text { LSAS, MOT, TANGOW } \\
\text { WHURLE, MASPLANG, } \\
\text { DEUS, WELSA, } \\
\text { MATHEMA, AMDPC, } \\
\text { LS-AEHS }\end{array}$ & $\begin{array}{l}\text { Arthur, ILASH, AHA! } \\
\text { (version 3.0) }\end{array}$ \\
\hline
\end{tabular}

As we can see from the Table 3, the most AEHS utilize models that come from the fourth family that accommodate learning styles as flexibly stable learning preferences. From the authors' point of view, Felder and Silverman's Learning Style Model is considered an appropriate measure for developing hypermedia courseware that should take into account personal factors [37]; has been recognized by many researchers as one of the most appropriate model for the development of adaptive learning environments [29]; the global-sequential dimension can be easily translated to hypertext and hypermedia structures and provide a logical scructure of information and/or navigational support [24]; its questionnaire gives the possibility of liking automatically results to learning environment [21]; had already been used successfully by many researchers, shows a good level of validity and reliability and uses multiple representations that could easily be rendered by different media [22]. Papadimitriou et al. [11] opt Kolb's model, as it can match the appropriate didactic strategies with user's learn- 
ing style, its concrete-abstract dimension is used for group formation and is suitable for the domain of Physics, namely for supporting didactic approaches for conceptual change. Papanikolaou et al. [19] choose Honey and Mumford's model in order for presentation of the educational material on each of the performance levels and Drissi \& Amirat [30] adopt the same model because is appropriate for presentation of pages and links at a hypermedia course. As far as the first family and Dunn and Dunn's Learning Style Model is concerned, its high index of reliability and validity, the breadth of six areas of learning preferences that covers [6] and the different presentation modes that serves, make it preferable [38]. According to [28], the VARK Learning Style Model is considered as the simplest model with the greatest influence.

As far as the second family is concerned, FI/FD cognitive styles are siginficant factor for hypermedia-based courseware's design and instruction [20]. Regarding the fifth family of learning styles, instructional strategies that suit to preferred learning styles with an option to switch it to a non-preferred version are adopted [17] and as stated in [16], instructional strategies can lessen the limitation of the tutor's ability to adapt to the learner's learning style.

From our point of view, an explanation of why the fourth family of learning styles, namely the flexibly stable learning preferences, is the most commonly-used is because the most AEHS are aimed at university students whose learning preferences are more fixed than younger ones. Also, the domains are complicated and require specific instructional design with appropriate strategies. In addition to this, it is obvious that the Felder and Silverman's model is generally accepted as the most comprehensive, handy and with construable results, thus many researchers implement it as safe option. Consequently, we deduce that the nature of subjects, the age and the technical features of instruments make a model and/or learning style family more or less "famous".

\section{$5 \quad$ Pedagogical basis of AEHS: the case of Adaptation Rules}

Various techniques are used in order to represent student models, such as rules, fuzzy logic, Bayesian networks and case-based reasoning [39]. An adaptation model is specified by adaptation rules which are "the adaptive methods and techniques used for content selection, navigation or presentation", according to [26] [pp. 21]. The development of adaptation rules is a daunting task and according to Popescu (2009) is " a delicate and tedious task", as requires interpretation of the literature in order to specify the instructional guidelines [8].

We report the rule-based systems and we present them according to Learning Style families. We do not refer the adaptation rules for the following systems AHA! 3.0, MOT, TANGOW, WHURLE, because are general-purpose AEH systems and the rules are defined by authors; at DEUS, FEIJOO.NET and PALS2 are not referred sufficient information in order to extract the adaptation rules and Arthur based on the Case-based Reasoning. As far as the format of adaptation rules, we follow the proposed in [5] for systems that adaptation rules have not specific format, while we maintain the format of systems that report them, for example the LS-AEHS system. 
As criteria to compare and present the adaptation rules, we employ the Learning Style Models and the corresponding learning preferences (learning style families).

We can deduce that AEC-CS and AMDPC, as described in Tables 8 and 4 that employ the Witkin's Learning Style Model in order to adapt the user interface to users' learning preferences, follow similar adaptation logic. In other words, the systems provide Field Dependent user with more information, more guidance and more complicated user interface, while Field Independent with less and more scructured information, no guidance and simplier user interface. Regarding the CS383 and MASPLANG, as we can see at Tables 5 and 6 , we observe that they have many similarities in terms of content selection and presentation. Specifically, they provide users with similar lesson structure and multimedia presentation, for instance, textual slides for verbals, pictorial format for visuals, overview for globals, etc. Regarding the LSAEHS and INSPIRE, as depicted in Tables 12 and 13, they have similarities to content's order and presentation order. For example, the two systems provide Activists with exploratory items, then present examples and theory and finally, practice. Concerning the system WELSA, the learning style model that applies is inspired by Herrmann's Whole Brain Model, Felder-Silverman Learning Style Model and Kolb's Learning Style Model. In terms of learning style preferences, there are similarities to content and presentation among CS383, AMDPC, MASPLANG and WELSA, as illustrated in Tables 5, 4, 6 and 16. Specifically, visual, verbal, active and reflective users are common and systems follow similar instructional guidelines in order to meet their needs. In terms of learning style families, we can claim that iWeaver and AEHSLS, as depicted in Tables 15 and 11 respectively, AES-CS and AMDPC, Tables 8 and 4 respectively, and finally, CS383, iWeaver, MASPLANG, WELSA and AMDPC, as shown by Tables 5, 15, 6, 16 and 4 share common learning style preferences, such as visual, verbal, active, reflective, sequential/serial, global/holistic, etc. and therefore, adopt similar instructional guidelines. For example, systems provide globals with overviews, verbals with audio files, sequentials with hierarchical structure of content, etc.

Consequently, we can infer that the adaptation rules are categorized primarily, on the basis of Learning Style Models, secondarily, on learning preferences and ulitmately, on adaptive hypermedia technologies without significant differences among them. This means that, systems that are based on the same model follow the same patterns, in terms of instructional guidelines and technologies (Adaptive navigation support and Adaptive presentation) that support the adaptation process.

Table 4. Adaptation Rules of AMDPC

\begin{tabular}{|c|c|}
\hline Content selection & \\
\hline $\begin{array}{l}\text { IF "Active" } € \text { LS } \text { Feldersilverman }_{\text {model }}(\mathrm{L}) \\
\text { THEN present Text: fundamental, Figure: fundamental \& } \\
\text { Example: fundamental \& supplementary }\end{array}$ & $\begin{array}{l}\text { IF "Reflective" } € \text { LS } \text { FelderSilverman_model }_{(L)} \\
\text { THEN present Text: fundamental, Figure: } \\
\text { fundamental \& Example: fundamental }\end{array}$ \\
\hline $\begin{array}{l}\text { IF "Sensing" } \in \text { LS FelderSilverman_model }(\mathrm{L}) \\
\text { THEN present Text: fundamental, Figure: fundamental \& } \\
\text { supplementary \& Example: fundamental \& supplementary }\end{array}$ & $\begin{array}{l}\text { IF "Intuitive" } \in \text { LS } \text { FelderSilverman_model }_{\text {I }}(\mathrm{L}) \\
\text { THEN present Text: fundamental \& } \\
\text { supplementary, Figure: fundamental \& Example: } \\
\text { fundamental \& supplementary }\end{array}$ \\
\hline
\end{tabular}


Paper-Adaptive Educational Hypermedia Systems based on Learning Styles: The Case of Adaptation..

\begin{tabular}{|c|c|}
\hline $\begin{array}{l}\text { IF "Visual" } \in \mathrm{LS}_{\text {FelderSilverman_model }}(\mathrm{L}) \\
\text { THEN present Text: fundamental, Figure: fundamental \& } \\
\text { supplementary \& Example: fundamental \& supplementary }\end{array}$ & $\begin{array}{l}\text { IF 'Text" } \in \text { LS FelderSilverman_model }(\mathrm{L}) \\
\text { THEN present Text: fundamental \& } \\
\text { supplementary, Figure: fundamental \& Example: } \\
\text { fundamental }\end{array}$ \\
\hline $\begin{array}{l}\text { IF "Sequential" } \in \text { LS } S_{\text {FelderSilverman model }}(\mathrm{L}) \\
\text { THEN present Text: fundamental \& supplementary, Figure: } \\
\text { fundamental, Example: fundamental \& Scope: a concept or } \\
\text { learning step }\end{array}$ & $\begin{array}{l}\text { IF "Global" } € \text { LS FelderSilverman_model }(\mathrm{L}) \\
\text { THEN present Text: fundamental with an abstract, } \\
\text { Figure: fundamental \& supplementary, Example: } \\
\text { fundamental \& supplementary \& Scope: a chapter }\end{array}$ \\
\hline \multicolumn{2}{|l|}{ Presentation } \\
\hline $\begin{array}{l}\text { IF "Field Dependent" } € \text { LS } \text { Witkin model }_{\text {m }}(\mathrm{L}) \\
\text { THEN present simpler interface, less information, only } \\
\text { frequently used functions and links to the information, } \\
\text { related to the current learning content }\end{array}$ & $\begin{array}{l}\text { IF "Field Independent" } € \text { LS Witkin_model }(\mathrm{L}) \\
\text { THEN present more complex interface, more } \\
\text { information, links to show the full functions of the } \\
\text { system and the schema of the entire learning } \\
\text { content }\end{array}$ \\
\hline
\end{tabular}

Table 5. Adaptation rules of CS383

\begin{tabular}{|c|c|}
\hline \multicolumn{2}{|l|}{ Content selection } \\
\hline $\begin{array}{l}\text { IF "Active" } € \text { LS Felder \& Silverman_model }(\mathrm{L}) \\
\text { THEN Knowledge nucleus, DOOM Scenario }\end{array}$ & $\begin{array}{l}\text { IF "Reflective" } € \text { LS Felder \& Silverman_model }(\mathrm{L}) \\
\text { THEN Lesson objectives, case studies, lectures, conceptual } \\
\text { maps }\end{array}$ \\
\hline IF "Sensing" $\epsilon$ LS Felder \& Silverman_model $(\mathrm{L})$ & IF "Intuitive" $€$ LS Felder \& Silverman_model $(\mathrm{L})$ \\
\hline $\begin{array}{l}\text { THEN Case studies, conceptual maps, DOOM } \\
\text { Scenario }\end{array}$ & THEN Lesson objectives detail the main concepts of the course \\
\hline $\begin{array}{l}\text { IF "Visual" } \epsilon \text { LS Felder \& Silverman_model }(\mathrm{L}) \\
\text { THEN virtual computer }\end{array}$ & $\begin{array}{l}\text { IF "Verbal" } \epsilon \text { LS Felder \& Silverman_model }(\mathrm{L}) \\
\text { THEN Lesson objectives provide a textual overview (words, } \\
\text { oral or written), virtual computer }\end{array}$ \\
\hline $\begin{array}{l}\text { IF "Sequential" } € \text { LS Felder \& Silverman_model }(\mathrm{L}) \\
\text { THEN Conceptual maps }\end{array}$ & $\begin{array}{l}\text { IF "Global" } \epsilon \text { LS Felder \& Silverman model }(\mathrm{L}) \\
\text { THEN Lesson objectives with lesson overview before the } \\
\text { details, jumping between different lessons, DOOM Scenario }\end{array}$ \\
\hline \multicolumn{2}{|l|}{ Presentation } \\
\hline $\begin{array}{l}\text { IF "Active" } € \text { LS Felder \& Silverman_model }(\mathrm{L}) \\
\text { THEN group discussions }\end{array}$ & $\begin{array}{l}\text { IF "Intuitive" } \in \text { LS } \\
\text { Felder \& Silverman_model } \\
\text { THEN slideshows, digital movies }\end{array}$ \\
\hline $\begin{array}{l}\text { IF "Sensing" } \epsilon \text { LS Felder \& Silverman_model }(\mathrm{L}) \\
\text { THEN hypertext, factual information, not } \\
\text { concepts, slideshows \& written papers }\end{array}$ & $\begin{array}{l}\text { IF "Verbal" } \in \text { LS Felder \& Silverman_model }(\mathrm{L}) \\
\text { THEN textual slides, course hypertext, sound files, written } \\
\text { papers \& slideshows }\end{array}$ \\
\hline $\begin{array}{l}\text { IF "Visual" } € \text { LS Felder \& Silverman_model }(\mathrm{L}) \\
\text { THEN full multimedia version of the } \\
\text { slideshow, video segments, digital movies, } \\
\text { graphics \& written papers }\end{array}$ & $\begin{array}{l}\text { IF "Global" } \epsilon \text { LS Felder \& Silverman_model }(\mathrm{L}) \\
\text { THEN digital movies, slideshows \& written papers }\end{array}$ \\
\hline $\begin{array}{l}\text { IF "Sequential" } \in \text { LS Felder \& Silverman_model }(\mathrm{L}) \\
\text { THEN sequential structure of the slideshows, } \\
\text { hierarchical structure of the hypertext, digital } \\
\text { movies }\end{array}$ & \\
\hline
\end{tabular}

Table 6. Adaptation rules of MASPLANG

\begin{tabular}{|c|c|c|}
\hline \multicolumn{3}{|l|}{ Content selection } \\
\hline $\begin{array}{l}\text { IF "Active" } € \text { LS } \\
\text { (L) } \\
\text { THEN Knowler \& Silverman model } \\
\end{array}$ & $\begin{array}{l}\text { IF "Reflective" } \epsilon \text { LS } \\
\text { Felder \& } \\
\text { Silverman model }(L) \\
\text { THEN Lesson objectives, case } \\
\text { studies, lectures, conceptual maps }\end{array}$ & $\begin{array}{l}\text { IF "Sensing" } \epsilon \text { LS Felder \& } \\
\text { Silverman model }(\mathrm{L}) \\
\text { THEN Case studies, conceptual } \\
\text { maps }\end{array}$ \\
\hline
\end{tabular}




\begin{tabular}{|c|c|c|}
\hline $\begin{array}{l}\text { IF "Intuitive" } € \text { LS Felder \& } \\
\text { Silverman model (L) } \\
\text { THEN Lesson objectives, } \\
\text { conceptual maps } \\
\text { IF "Sequential" } € \text { LS Felder \& } \\
\text { Silverman_model (L) } \\
\text { THEN Conceptual maps }\end{array}$ & $\begin{array}{l}\text { IF "Visual" } € \text { LS } \text { Felder \& Silverman_model } \\
\text { (L) } \\
\text { THEN } \\
\text { Case studies, conceptual maps, } \\
\text { synthesis } \\
\text { IF "Global" } € \text { LS Felder \& Silverman_model } \\
\text { (L) } \\
\text { THEN Lesson objectives, synthesis }\end{array}$ & $\begin{array}{l}\text { IF "Verbal" } € \text { LS Felder \& } \\
\text { Silverman model }(\mathrm{L}) \\
\text { THEN Lesson objectives, } \\
\text { lectures, conceptual maps }\end{array}$ \\
\hline \multicolumn{3}{|l|}{ Navigation } \\
\hline $\begin{array}{l}\text { IF "Active" } € \text { LS Felder \& Silverman_model } \\
\text { (L) } \\
\text { THEN arrows (back \& forward), } \\
\text { printings, general vision maps, } \\
\text { filters, chat, forum, e-mail }\end{array}$ & $\begin{array}{l}\text { IF "Reflective" } € \text { LS Felder \& } \\
\text { Silverman_model (L) } \\
\text { THEN arrows (back \& forward), } \\
\text { printings, on-line help, general vision } \\
\text { maps, filters, e-mail }\end{array}$ & $\begin{array}{l}\text { IF "Sensing" } \in \text { LS Felder \& } \\
\text { Silverman_model (L) } \\
\text { THEN arrows (back \& forward), } \\
\text { printings, on-line help, general } \\
\text { vision maps, filters, chat, forum, } \\
\text { e-mail }\end{array}$ \\
\hline $\begin{array}{l}\text { IF "Intuitive" } \epsilon \text { LS Felder \& } \\
\text { Silverman model }(\mathrm{L}) \\
\text { THEN arrows (back \& forward), } \\
\text { printings, on-line help, general } \\
\text { vision maps, filters, chat, forum, e- } \\
\text { mail }\end{array}$ & $\begin{array}{l}\text { IF "Visual" } € \text { LS } S_{\text {Felder \& Silverman model }} \\
\text { (L) } \\
\text { THEN arrows (back \& forward), } \\
\text { printings, on-line help, general vision } \\
\text { maps, filters, chat, forum, e-mail }\end{array}$ & $\begin{array}{l}\text { IF "Verbal" } € \text { LS } \text { Felder \& } \\
\text { Silverman model }(\mathrm{L}) \\
\text { THEN arrows (back \& forward) } \\
\text { printings, on-line help, general } \\
\text { vision maps, filters, chat, forum, } \\
\text { e-mail }\end{array}$ \\
\hline $\begin{array}{l}\text { IF "Sequential" } \in \text { LS } \text { Felder \& } \\
\text { Silverman model (L) } \\
\text { THEN arrows (back \& forward) } \\
\text { printings, on-line help, chat, forum, } \\
\text { e-mail } \\
\text { Presentation }\end{array}$ & $\begin{array}{l}\text { IF "Global" } € \text { LS } \text { Felder \& Silverman model } \\
\text { (L) } \\
\text { THEN general vision maps, filters, } \\
\text { chat, forum, e-mail }\end{array}$ & \\
\hline $\begin{array}{l}\text { IF "Active" } € \text { LS Felder \& Silverman_model } \\
\text { (L) } \\
\text { THEN lineal text }\end{array}$ & $\begin{array}{l}\text { IF "Reflective" } € \text { LS Felder \& } \\
\text { Silverman_model }(\mathrm{L}) \\
\text { THEN text, lineal text }\end{array}$ & $\begin{array}{l}\text { IF "Sensing" } \epsilon \text { LS Felder \& } \\
\text { Silverman_model }(\mathrm{L}) \\
\text { THEN multimedia, graphics, } \\
\text { digital movies, audio, lineal text }\end{array}$ \\
\hline $\begin{array}{l}\text { IF "Intuitive" } € \text { LS Felder \& } \\
\text { Silverman_model }(\mathrm{L}) \\
\text { THEN text, multimedia, graphics, } \\
\text { digital movies, audio }\end{array}$ & $\begin{array}{l}\text { IF "Visual" } € \text { LS Felder \& Silverman_model } \\
\text { (L) } \\
\text { THEN multimedia, graphics, digital } \\
\text { movies }\end{array}$ & $\begin{array}{l}\text { IF "Verbal" } € \mathrm{LS}_{\text {Felder \& }} \\
\text { Silverman_model }(\mathrm{L}) \\
\text { THEN text, audio }\end{array}$ \\
\hline $\begin{array}{l}\text { IF "Sequential" } € \text { LS Felder \& } \\
\text { Silverman_model }(\mathrm{L}) \\
\text { THEN text, multimedia, digital } \\
\text { movies, audio }\end{array}$ & $\begin{array}{l}\text { IF "Global" } € \text { LS Felder \& Silverman_model } \\
\text { (L) } \\
\text { THEN digital movies }\end{array}$ & \\
\hline
\end{tabular}

Table 7. Adaptation rules of TANGOW

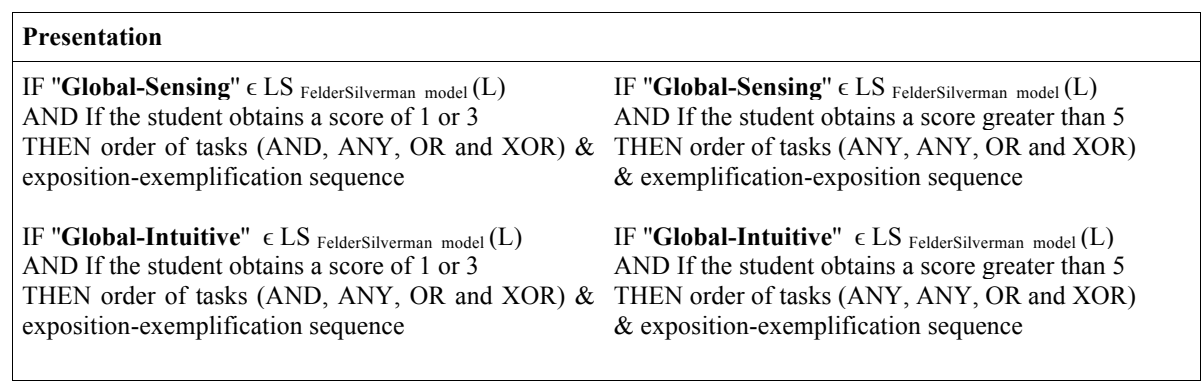


IF "Sequential-Sensing" $\epsilon$ LS FelderSilverman model $(\mathrm{L})$

AND If the student obtains a score of 1 or 3

2

(AND, ANY,

IF "Sequential-Intuitive" $\epsilon$ LS FelderSilverman model $(\mathrm{L})$

AND If the student obtains a score of 1 or 3

THEN order of tasks (AND, ANY, OR and XOR)

exposition-exemplification sequence
IF "Sequential-Sensing" $\in$ LS AND If the student obtains a score greater than 5
THEN order of tasks (AND, AND, OR and XOR)

$\&$ exemplification-exposition sequence

IF "Sequential-Intuitive" $\epsilon$ LS FelderSilverman model $(\mathrm{L})$ AND If the student obtains a score greater than 5 THEN order of tasks (AND, AND, OR and XOR) $\&$ exposition-exemplification sequence

Table 8. Adaptation rules of AES-CS

\begin{tabular}{|c|c|}
\hline \multicolumn{2}{|l|}{ Navigation } \\
\hline IF "Field Dependent" $€$ LS Witkin model $_{\text {(L) }}$ & IF "Field Independent" $\epsilon$ LS Witkin model $(\mathrm{L})$ \\
\hline THEN provide program control (no menu) & THEN provide learner control (menu) \\
\hline IF "Field Dependent" $\epsilon$ LS Witkin model $(\mathrm{L})$ & IF "Field Independent" $€$ LS Witkin model $_{(\mathrm{L})}$ \\
\hline THEN provide maximum instructions & THEN provide minimal instructions (only the initial instructions) \\
\hline IF "Field Dependent" $\epsilon$ LS witkin model $(\mathrm{L})$ & IF "Field Independent" $\in$ LS Witkin_model $(\mathrm{L})$ \\
\hline THEN provide maximum feedback & THEN provide minimal feedback \\
\hline IF "Field Dependent" $\epsilon$ LS Witkin model $(\mathrm{L})$ & IF "Field Independent" $€$ LS Witkin model $_{(L)}$ \\
\hline THEN provide structured lessons & THEN learners develop their own structure \\
\hline \multicolumn{2}{|l|}{ Presentation } \\
\hline IF "Field Dependent" $\epsilon$ LS Witkin model $_{\text {(L) }}$ & IF "Field Independent" $\in$ LS ${ }_{\text {Witkin model }}(\mathrm{L})$ \\
\hline THEN provide global approach & THEN provide analytical approach \\
\hline IF "Field Dependent" $\epsilon$ LS Witkin model $_{(L)}$ & IF "Field Independent" $\epsilon$ LS Witkin model $(\mathrm{L})$ \\
\hline THEN provide advance organizers & THEN provide illustrative post organizers \\
\hline
\end{tabular}

Table 9. Adaptation rules of ILASH

\section{Navigation}

If score after each lesson is correct

THEN The "Summarising strategy" is preferred by the student, keep on using S type pages [a top-down approach where the material is presented with key-points summarised at the end of each page \& provides contextual clues to help students with getting the gist of information (by using headings, diving text in small chunks etc)]

ELSE The "Summarising strategy" is NOT preferred, a "Questioning strategy" needed ENDIF

If score after each lesson is correct

THEN The "Questioning strategy" is preferred by the student, keep on using Q_type pages [have a question asked after each paragraph (which contains an explanation of a concept)]

ELSE The "Questioning strategy" is NOT preferred, a "Summarizing strategy" needed ENDIF

Table 10. Adaptation rules of LSAS

\begin{tabular}{|ll|}
\hline Navigation & \\
\hline IF "Sequential" $€$ LS FelderSilverman_model (L) & IF "Global" $€$ LS Feldersilverman model (L) \\
$\begin{array}{l}\text { THEN present "Sequential page layout" (small } \\
\text { chunks of information, text-only pages with 'forward' } \\
\text { \& 'back' buttons) }\end{array}$ & $\begin{array}{l}\text { THEN present "Global page layout" (elements, such } \\
\text { as a table of contents, summary, diagrams, overview of } \\
\text { information, etc.) }\end{array}$ \\
\hline
\end{tabular}


Paper-Adaptive Educational Hypermedia Systems based on Learning Styles: The Case of Adaptation...

Table 11. Adaptation rules of AEHS-LS

\begin{tabular}{|c|c|}
\hline Presentation & \\
\hline $\begin{array}{l}\text { IF "Visual preference" } \epsilon \text { LS VARK model }(\mathrm{L}) \\
\text { THEN include the depiction of information in maps, } \\
\text { diagrams, flow charts \& all the symbolic arrows }\end{array}$ & $\begin{array}{l}\text { IF "Auditory preference" } € \text { LS VARK model }(\mathrm{L}) \\
\text { THEN present information that is "heard or spoken" }\end{array}$ \\
\hline $\begin{array}{l}\text { IF "Read/write preference" } \epsilon \text { LS } \text { VARK_model }_{\text {IF }}(\mathrm{L}) \\
\text { THEN display information as text }\end{array}$ & $\begin{array}{l}\text { IF "Kinesthetic preference" } \epsilon \text { LS }{ }_{\text {VARK model }}(\mathrm{L}) \\
\text { THEN provide opportunities for use of experience \& } \\
\text { practice }\end{array}$ \\
\hline
\end{tabular}

Table 12.

Adaptation rules of AEHS-LS

\begin{tabular}{l}
\hline Navigation \\
If LS "H \& M" (learner) = "activist"” Then Appear in the top of page exploratory learning objects followed by \\
links to illustrative learning objects, theoretical learning objects and interactive learning objects \\
If LS "H \& M" (learner) = "reflector" Then Appear in the top of page illustrative learning objects followed by \\
links to theoretical learning objects, interactive learning objects and exploratory learning objects \\
If LS "H \& M" (learner) = "theorist"” Then Appear in the top of page theoretical learning objects followed by \\
links to interactive learning objects, exploratory learning objects and learning objects \\
If LS "H \& M" (learner) = "pragmatist" Then Appear in the top of page interactive learning objects followed \\
by links to exploratory learning objects, illustrative learning objects and theoretical learning objects \\
\hline Presentation \\
If LS "H \& M" (learner)="activist" Then apply exploratory mode \\
Else if LS "H \& M" (learner)="reflector" Then apply reflective mode \\
Else if LS "H \& M" (learner)="theorist" Then apply abstract mode \\
Else if LS "H \& M" (learner)="pragmatist" Then apply verification mode
\end{tabular}

Table 13.

Adaptation rules of INSPIRE

Content selection

IF the knowledge level of the learner has been evaluated as \{Inadequate\} on outcome concepts

THEN these outcome concepts \& their entire set of prerequisite concepts is recommended to the learner

IF the knowledge level of the learner has been evaluated as $\{$ Mediocre\} or $\{$ Advanced $\}$ on outcome concepts $\&$ \{Proficient\} on several of their prerequisite concepts

THEN these outcome concepts $\&$ the rest of their prerequisites are recommended to the learner

IF the knowledge level of the learner has been evaluated as \{Inadequate\} on outcome concepts

THEN educational material of the Remember level of performance for these outcome concepts \& material for their prerequisite concepts that are included in the lesson contents, is proposed to the learner

IF the knowledge level of the learner has been evaluated as \{Mediocre\} on outcome concepts

THEN educational material of the Use level of performance for these outcome concepts \& material for their

prerequisite concepts that are included in the lesson contents, is proposed to the learner

IF the knowledge level of the learner has been evaluated as \{Advanced\} on outcome concepts

THEN educational material of the Find level of performance for these outcome concepts \& material for their prerequisite concepts that are included in the lesson contents, is proposed to the learner

Navigation

If learner's knowledge level has been evaluated as \{Inadequate\} with regards to a specific outcome concept THEN next to its title in the Navigation Area an empty measuring cup appears

If learner's knowledge level has been evaluated as \{Mediocre\} with regards to a specific outcome concept 
Paper-Adaptive Educational Hypermedia Systems based on Learning Styles: The Case of Adaptation...

THEN next to its title in the Navigation Area a half empty measuring cup appears

If learner's knowledge level has been evaluated as \{Advanced\} with regards to a specific outcome concept THEN next to its title in the Navigation Area an almost full measuring cup appears

\begin{tabular}{|c|c|}
\hline Presentation & \\
\hline $\begin{array}{l}\text { IF "Activist" } \in \mathrm{LS}_{\mathrm{H} \& \mathrm{M} \text { model }}(\mathrm{L}) \\
\text { THEN present activity, example, theory \& practice }\end{array}$ & IF "Reflector" $€ \mathrm{LS}_{\mathrm{H} \& \mathrm{M} \text { model }}(\mathrm{L})$ \\
\hline IHEN present activity, example, theory $\&$ practice & THEN present example, theory, practice \& activity \\
\hline $\begin{array}{l}\text { IF "Theoretical" } \epsilon \text { LS } \mathrm{H} \& \mathrm{M} \text { model }(\mathrm{L}) \\
\text { THEN present theory, example, exercise \& activity }\end{array}$ & $\begin{array}{l}\text { IF "Pragmatist" } € \mathrm{LS}_{\mathrm{H}} \& \mathrm{M} \text { model }(\mathrm{L}) \\
\text { THEN present exercise, example, theory \& activity }\end{array}$ \\
\hline
\end{tabular}

Table 14.

Adaptation rules of MATHEMA

\begin{tabular}{|c|c|}
\hline \multicolumn{2}{|l|}{ Navigation } \\
\hline $\begin{array}{l}\text { IF the learner is not ready to study because the } \\
\text { necessary prerequisite main concepts were not met }\end{array}$ & $\begin{array}{l}\text { IF the learner has already studied and has succeeded } \\
\text { in the assessment tests }\end{array}$ \\
\hline THEN Links to the main concepts are colored red & THEN Links to the main concepts are colored yellow \\
\hline IF the learner is ready to study & IF the learner is ready to study \\
\hline $\begin{array}{l}\text { THEN Links to the main concepts with low degree of } \\
\text { difficulty are colored light green }\end{array}$ & $\begin{array}{l}\text { THEN Links to the main concepts with medium } \\
\text { degree of difficulty are colored green }\end{array}$ \\
\hline $\begin{array}{l}\text { IF the learner is ready to study } \\
\text { THEN Links to the main concepts with high degree of } \\
\text { difficulty are colored dark green }\end{array}$ & $\begin{array}{l}\text { IF the learner is ready to study } \\
\text { THEN Links to the main concepts with medium } \\
\text { degree of difficulty are colored green }\end{array}$ \\
\hline \multicolumn{2}{|l|}{$\begin{array}{l}\text { IF the learner has already studied but he/she has } \\
\text { successfully assessed in the assessment tests } \\
\text { THEN Links to the main concepts are colored orange }\end{array}$} \\
\hline \multicolumn{2}{|l|}{ Presenation } \\
\hline IF "Diverger" $€$ LS KOLB_model $_{\text {(L) }}$ & IF "Assimilator" $\in$ LS KOLB_model $_{\text {(L) }}$ \\
\hline $\begin{array}{l}\text { THEN present questions using analogies and/or video } \\
\text { simulations, theory and examples, exercise solving \& } \\
\text { problem solving activity }\end{array}$ & $\begin{array}{l}\text { THEN present theory and examples, exercise solving, } \\
\text { problem solving activity \& questions using analogies } \\
\text { and/or video simulations }\end{array}$ \\
\hline IF "Converger" $\epsilon$ LS $S_{\text {KOLB model }}(\mathrm{L})$ & IF "Accommodator" $€$ LS KOLB_model $_{(L)}$ \\
\hline $\begin{array}{l}\text { THEN present exercise solving, problem solving } \\
\text { activity, questions using analogies and/or video } \\
\text { simulations \& theory and examples }\end{array}$ & $\begin{array}{l}\text { THEN present problem solving activity, questions } \\
\text { using analogies and/or video simulations, theory and } \\
\text { examples \& exercise solving }\end{array}$ \\
\hline
\end{tabular}

Table 15.

Adaptation rules of iWeaver

\begin{tabular}{|ll|}
\hline Navigation & \\
\hline $\begin{array}{l}\text { IF "Impulsive" } \epsilon \text { LS Dunn \& Dunn_model (L) } \\
\text { THEN Try-it button (allows immediate trial) (Additional } \\
\text { tool) }\end{array}$ & $\begin{array}{l}\text { IF "Reflective" } \epsilon \text { LS Dunn \& Dunn_model (L) } \\
\text { THEN Context-aware note-taking tool, questions } \\
\text { that encourage reflection (Additional tool) }\end{array}$ \\
$\begin{array}{l}\text { IF "Global" } \epsilon \text { LS Dunn \& Dunn_model (L) } \\
\text { THEN Advance organisers (full-tree view) or mind maps } \\
\text { (Additional multimedia representation) }\end{array}$ & $\begin{array}{l}\text { IF "Analytical" } € \text { LS Dunn \& Dunn_model (L) } \\
\text { THEN Sequential lists of key points and } \\
\text { components [Text (default)] }\end{array}$ \\
\hline Presentation & \\
\hline $\begin{array}{l}\text { IF "Auditory" } \epsilon \text { LS Dunn \& Dunn_model (L) } \\
\text { THEN PowerPoint-style presentations with synchronous } \\
\text { audio, no text (Multimedia representation) }\end{array}$ & $\begin{array}{l}\text { IF "Visual (Pictures)" } \epsilon \text { LS Dunn \& Dunn_model (L) } \\
\text { THEN Diagrams, illustrations, graphs, flowcharts, } \\
\text { animations+audio (Multimedia representation text } \\
\text { or audio) }\end{array}$ \\
\hline
\end{tabular}


IF "Visual (Text)" $\in$ LS Dunn \& Dunn model (L)

THEN reading, context-aware note-taking tool

(Text+additional tool)

IF "Internal Kinesthetic" $\epsilon$ LS Dunn \& Dunn model $(\mathrm{L})$

THEN Extra examples of real-life relevance, links to

prior content (Additional text)
IF "Tactile Kinesthetic" $€$ LS Dunn \& Dunn model (L) THEN Interactive multimedia elements (interactivelets): puzzles, drag \& drop, fill-ins, small games (Multimedia representation+text)

Table 16.

Adaptation rules of WELSA

\begin{tabular}{|c|c|c|}
\hline \multicolumn{3}{|l|}{ Navigation } \\
\hline $\begin{array}{l}\text { IF } p \_ \text {holistic } \in \text { Pref }(L) \\
\text { THEN Highlight Outline } \\
\text { Dim Next_Button, Prev_Button } \\
\text { Hide Next_Button,Prev_Button } \\
\{\text { bottomPage } \\
\text { Highlight LoType }\{\text { AdditionalInfo }\}\end{array}$ & $\begin{array}{l}\text { IF } p \_ \text {serial } € \text { Pref }(L) \\
\text { THEN Highlight Next_Button } \\
\text { Dim Outline, Prev_Button } \\
\underline{\text { Hide Outline,Prev_Button }} \\
\{\text { bottomPage }\} \\
\text { Dim LoType }\{\text { AdditionalInfo }\}\end{array}$ & $\begin{array}{l}\text { IF } p \_ \text {carefulDetails } \in \text { Pref }(L) \\
\text { THEN Highlight LoType } \\
\{\text { Additionifo, Remark, Evidence }\} \\
\text { IF } p \text { notCarefulDetails } € \text { Pref }(L) \\
\text { THEN Dim LoType }\{\text { Additionifo, } \\
\text { Remark, Evidence }\}\end{array}$ \\
\hline \multicolumn{3}{|l|}{ Presentation } \\
\hline $\begin{array}{l}\text { IF } p \text { _visual } € \text { Pref }(L) \\
\text { THEN Sort } d c: \text { type }\{\text { Stillmage } \\
\text { /MovingImage, Text } / \text { Sound }\} \\
\text { Dim } d c: \text { type }\{\text { Text, Sound }\}\end{array}$ & $\begin{array}{l}\text { IF } p_{\text {_ verbal }} \in \text { Pref }(L) \\
\text { THEN Sort } d c: \text { type }\{\text { Text } \\
\text { /Sound, Stillmage /MovingImage }\} \\
\text { Dim } d c: \text { type }\{\text { Stillmage } \\
\text { /MovingImage }\}\end{array}$ & $\begin{array}{l}\text { IF } p \_a c t i v e \text { Experimentation } € \text { Pref } \\
\text { (L) } \\
\text { THEN Sort LoType \{Interactivity, } \\
\text { Fundamental /Illustration\} } \\
\text { Highlight LoType \{Interactivity\} }\end{array}$ \\
\hline $\begin{array}{l}\text { IF } p \_ \text {reflectiveObservation } € \text { Pref } \\
\text { (L) } \\
\text { THEN Sort LoType }\{\text { Fundamental } \\
\text { /Illustration, Interactivity }\} \\
\text { Dim LoType }\{\text { Interactivity }\}\end{array}$ & $\begin{array}{l}\text { Highlight Chat, Forum } \\
\text { IF p_abstract } € \text { Pref }(L) \\
\text { THEN Sort LoType } \\
\text { \{Fundamental, Illustration }\} \\
\text { Highlight LoType \{Fundamental\} }\end{array}$ & $\begin{array}{l}\text { IF } p \_ \text {concrete } € \text { Pref }(L) \\
\text { THEN Sort LoType }\{\text { Illustration, } \\
\text { Fundamental\} } \\
\text { Hightlight LoType }\{\text { Illustration\} }\end{array}$ \\
\hline $\begin{array}{l}\text { IF } p \text { individual } \in \text { Pref }(L) \\
\text { THEN Highlight hasCompetency } \\
\{\text { individual }\} \\
\text { Dim hasCompetency }\{\text { team }\} \\
\text { Dim Chat, Forum }\end{array}$ & $\begin{array}{l}\text { IF } p \_ \text {team } \in \text { Pref }(L) \\
\text { THEN Highlight hasCompetency } \\
\{\text { team }\} \\
\text { Dim hasCompetency \{individual }\} \\
\text { Highlight Chat, Forum }\end{array}$ & \\
\hline
\end{tabular}

\section{Conclusion and Future Work}

In order to accommodate users' learning style preferences and needs, AEHSystems utilize learning styles models as a way of modelling user's preferences, aiming at provision of personalized content or/and navigation advice. We can assume that user modelling has changed, as the employed learning style preferences allow more flexible and personal adaptation to each user. Within this context, the development of metacognitive ability can be achieved and self-regulated learning can be cultivated, as the students can obtain awareness of their learning needs and preferences. The contribution of this work is that there are not similar works, at least from 2003, that investigate the pedagogical basis of AEHS and thus, could trigger similar undertakings. With regard to teaching, the work's contribution can be located on the utilization of Learning Style Models in educational process. Educators can improve the students' 
performance with or without learning disabilities through instruction's individualization to students' needs. Future works could study the pedagogical basis at a more broaden scope, including AEHS that do not utilize Learning Style Models.

\section{$7 \quad$ References}

[1] Lin, B., \& Hsieh, C. T. "Web-based teaching and learner control: A research review". Computers \& Education, 37(3), 377-386, 2001 https://doi.org/10.1016/S03601315(01)00060-4

[2] Neo, M., Neo, T. K., \& Yap, W. L. "Students' perceptions of interactive multimedia mediated web-based learning: A Malaysian perspective". In Proceedings of ASCILITE 2008 Conference, Melbourne, 2008

[3] Brusilovsky, P. \& Peylo, C. "Adaptive and intelligent Web-based educational systems". International Journal of Artificial Intelligence in Education, 13 (2-4), 159-172, 2003

[4] Popescu, Elvira, Philippe Trigano, and Costin Badica. "Towards a Unified Learning Style Model in Adaptive Educational Systems." Seventh IEEE International Conference on Advanced Learning Technologies (ICALT 2007), 2007. https://doi.org/10.1109/ICALT. 2007.263

[5] Popescu, E., Badica, C., \& Trigano, P. "Rules for learner modeling and adaptation provisioning in an educational hypermedia system". In Symbolic and Numeric Algorithms for Scientific Computing, 2007. SYNASC. International Symposium on (pp. 492-499). IEEE, 2007 https://doi.org/10.1109/synasc.2007.72

[6] Wolf, C. "iWeaver: towards' learning style'-based e-learning in computer science education". In Proceedings of the fifth Australasian conference on Computing education-Volume 20 (pp. 273-279). Australian Computer Society, Inc, 2003

[7] Al-Azawei, Ahmed, and Atta Badii. "State of The Art of Learning Styles-Based Adaptive Educational Hypermedia Systems (Ls-Baehss)." International Journal of Computer Science and Information Technology 6, no. 3 (2014): 01-19. https://doi.org/10.5121/ijcsit. 2014.6301

[8] Popescu, Elvira. "Diagnosing Students' Learning Style in an Educational Hypermedia System." Cognitive and Emotional Processes in Web-Based Education: 187-208. https://doi.org/10.4018/978-1-60566-392-0.ch011

[9] Mulwa, C., Lawless, S., Sharp, M., Arnedillo-Sanchez, I., \& Wade, V. "Adaptive educational hypermedia systems in technology enhanced learning: a literature review". In Proceedings of the 2010 ACM conference on Information technology education (pp. 73-84), 2010 https://doi.org/10.1145/1867651.1867672

[10] Stash, Natalia Victorovna, Alexandra Ioana Cristea, and Paul M. De Bra. "Authoring of learning styles in adaptive hypermedia." Alternate track papers \& posters of the 13th international conference on World Wide Web - WWW Alt. '04, 2004. https://doi.org/10.1145/1010432.1010452

[11] Papadimitriou, A., Grigoriadou, M., \& Gyftodimos, G. "MATHEMA: A Learnercontrolled Adaptive Educational Hypermedia System". Journal of Information Technology and Application in Education, 1(2), 47-73, 2012

[12] Vandewaetere, Mieke, Piet Desmet, and Geraldine Clarebout. "The contribution of learner characteristics in the development of computer-based adaptive learning environments." Computers in Human Behavior 27, no. 1 (2011): 118-30. https://doi.org/10.1016/ j.chb.2010.07.038

[13] Özyurt, Özcan, Hacer Özyurt, and Adnan Baki. "Design and development of an innovative individualized adaptive and intelligent e-learning system for teaching-learning of probabil- 
Paper-Adaptive Educational Hypermedia Systems based on Learning Styles: The Case of Adaptation...

ity unit: Details of UZWEBMAT." Expert Systems with Applications 40, no. 8 (2013): 2914-940. https://doi.org/10.1016/j.eswa.2012.12.008

[14] Sampson, D., \& Karagiannidis, C. "Personalised learning: Educational, technological and standardisation perspective". Interactive educational multimedia, (4), 24-39, 2010

[15] Carver, C. A., Howard, R. A., \& Lavelle, E., "Enhancing student learning by incorporating learning styles into adaptive hypermedia." In Proceedings of Ed-Media, Vol. 96, (pp. 118123), 1996

[16] J. E.Gilbert and Han, C. Y. "Adapting instruction in search of 'a significant difference'". Journal of Network and Computer applications, 22(3), 149-160, 1999 https://doi.org/10.1006/jnca.1999.0088

[17] "Incorporating learning styles in hypermedia environment: Empirical evaluation." Incorporating learning styles in hypermedia environment: empirical evaluation. Accessed March 30, 2017. http://wwwis.win.tue.nl/ah2003/proceedings/www-4/

[18] Ruiz, M. D. P. P., Barriales, S. O., Pérez, J. R. P., \& Rodríguez, M. G. "Feijoo. net: an approach to personalized E-learning using learning styles". In International Conference on Web Engineering (pp. 112-115). Springer Berlin Heidelberg, 2003

[19] Papanikolaou, K. A., Grigoriadou, M., Kornilakis, H., \& Magoulas, G. D. "Personalizing the Interaction in a Web-based Educational Hypermedia System: the case of INSPIRE". User modeling and user-adapted interaction, 13(3), 213-267, 2003 https://doi.org/10.1023/A:1024746731130

[20] Triantafillou, Evangelos, Andreas Pomportsis, and Stavros Demetriadis. "The design and the formative evaluation of an adaptive educational system based on cognitive styles." Computers \& Education 41, no. 1 (2003): 87-103. https://doi.org/10.1016/S03601315(03)00031-9

[21] Paredes, P., and P. Rodriguez. "A Mixed Approach to Modelling Learning Styles in Adaptive Educational Hypermedia." Advanced Technology for Learning 1, no. 4 (2004). https://doi.org/10.2316/Journal.208.2004.4.208-0823

[22] Brown, Elizabeth, Tim Brailsford, Tony Fisher, Adam Moore, and Helen Ashman. "Reappraising cognitive styles in adaptive web applications." Proceedings of the 15th international conference on World Wide Web - WWW '06, 2006. https://doi.org/10.1145/ 1135777.1135827

[23] Peña, C. I., Marzo, J. L., \& de la Rosa, J. L. "Curriculum sequencing for an e-learning system based on learning styles". In Information Technology Based Higher Education and Training, 2004. ITHET 2004. Proceedings of the FIfth International Conference on (pp. 167-172). IEEE

[24] Brown, Elizabeth, Tony Fisher, and Tim Brailsford. "Real users, real results." Proceedings of the 18th conference on Hypertext and hypermedia - HT '07, 2007. https://doi.org/10.1145/1286240.1286261

[25] Stash, Natalia. "Incorporating cognitive/learning styles in a general-purpose adaptive hypermedia system." ACM SIGWEB Newsletter 2007, no. Winter (2007). https://doi.org/10.1145/1324960.1324963

[26] E. Popescu, "Dynamic adaptive hypermedia systems for e-learning". Ph.D. dissertation, Université de Technologie de Compiègne, 2008

[27] Siadaty, Melody, and Fattaneh Taghiyareh. "PALS2: Pedagogically Adaptive Learning System based on Learning Styles." Seventh IEEE International Conference on Advanced Learning Technologies (ICALT 2007), 2007. https://doi.org/10.1109/ICALT.2007.198

[28] Mustafa, Y. E. A., \& Sharif, S. M. "An approach to adaptive e -learning hypermedia system based on learning styles (AEHS-LS): Implementation and evaluation". International Journal of Library and Information Science, 3(1), 15-28, 2011

[29] Yang, T. C., Hwang, G. J., \& Yang, S. J. H. "Development of an adaptive learning system with multiple perspectives based on students' learning styles and cognitive styles". Journal of Educational Technology \& Society, 16(4), 185-200, 2013 
Paper-Adaptive Educational Hypermedia Systems based on Learning Styles: The Case of Adaptation...

[30] Drissi, Samia, and Abdelkrim Amirat. "An adaptive e-learning hypermedia system: Design and evaluation." 2013 3rd International Symposium ISKO-Maghreb, 2013. https://doi.org/10.1109/ISKO-Maghreb.2013.6728106

[31] Keefe, J.W. "Learning style: an overview". In J.W. Keefe, editor, Student learning styles: diagnosing and prescribing programs. NASSP, 1979

[32] Witkin, H. A., \& Goodenough, D. R. "Cognitive styles: essence and origins. Field dependence and field independence". Psychological issues, (51), 1-141, 1980

[33] Ausubel, David Paul. Educational psychology ; a cognitive view. New York: Holt., 1968

[34] Riding, R., \& Rayner, S. "Cognitive styles and learning strategies: Understanding style differences in learning and behavior". Routledge, 2013

[35] Coffield, F., Moseley, D., Hall, E., \& Ecclestone, K. "Learning styles and pedagogy in post-16 learning: A systematic and critical review", 2004

[36] Curry, L. "An Organization of Learning Styles Theory and Constructs", 1983

[37] Carver, C.a., R.a. Howard, and W.d. Lane. "Enhancing student learning through hypermedia courseware and incorporation of student learning styles." IEEE Transactions on Education 42, no. 1 (1999): 33-38. https://doi.org/10.1109/13.746332

[38] Klasnja-Milicevic, Aleksandra, Boban Vesin, Mirjana Ivanovic, and Zoran Budimac. "Integration of recommendations and adaptive hypermedia into java tutoring system." Computer Science and Information Systems 8, no. 1 (2011): 211-24. https://doi.org/10.2298/CSIS090608021K

[39] García, P., Amandi, A., Schiaffino, S., \& Campo, M. "Evaluating Bayesian networks' precision for detecting students' learning styles". Computers \& Education, 49(3), 794-808, 2007 https://doi.org/10.1016/j.compedu.2005.11.017

\section{$8 \quad$ Authors}

Xanthippi Tsortanidou holds a Master of Education on "Contemporary Learning Environments and Curriculum Development" and a Bachelor of Primary Education from the University of Thessaly, Greece. Her research interests are in the area of adaptive educational environments and in particular the exploration of pedagogical basis and the use of learning styles.

Charalampos Karagiannidis is Professor for ICT Applications in Learning \& Special Education at the Department of Special Education, University of Thessaly, Greece. His research interests are in the area of intelligent user interfaces and their use to improve access for people with disabilities. He had been one of the first to conduct research in what would be nowadays regarded as Big Data for human-computer interaction, with use of mixed research methods that make use of applied mathematics to improve decision making for improving quality of access to information.

Adamantios Koumpis is scientific collaborator at the Universität Passau, Lehrstuhl für Informatik mit Schwerpunkt Digital Libraries and Web Information Systems. Till June 2014 Adamantios was Research Fellow at the Digital Enterprise Research Institute of the National University of Ireland, Galway. Before this, Adamantios headed the Research Programmes Division of ALTEC Software S.A., which he founded in 1996.

Article submitted 31 March 2017. Published as resubmitted by the authors 15 May 2017. 